\title{
PENDIDIKAN WANITA \\ DALAM FILSAFAT PENDIDIKAN ISLAM
}

\author{
Zulham Effendi \\ Program Studi Pendidikan Bahasa Arab STAI As-Sunnah \\ J1. Medan-Tj. Morawa, Gg. Darmo, Bangun Sari, Tj. Morawa, Deli Serdang SUMUT \\ zlhm.eff@gmail.com
}

\begin{abstract}
Abstrak: Wanita dalam Islam memiliki hak yang sama dalam pendidikan. Nabi secara umum menjelaskan bahwa belajar itu wajib hukumnya atas setiap muslim termasuk wanita. Islam tidak melarang para wanita untuk belajar agama. Tidak mengapa bagi para wanita untuk mencari jalan kemajuan bagi dirinya. Bahkan para ahlul ilmi dan ahli fiqh zaman terdahulu maupun sekarang sepakat, bahwa menuntut ilmu syar'i yang menjadi kebutuhan pokok adalah fardhu 'ain atas mereka. Tidak ada perbedaan antara laki-laki dengan perempuan dalam hal ini. Laki-laki dan perempuan memiliki kedudukan yang sama dalam kewajiban bersyariat, dan begitu pula dalam mendapatkan balasan di akhirat, kecuali dalam beberapa aturan syariat tertentu, Allah Subhanahu wa Ta'ala membebaskan kaum wanita dari tugas tersebut.
\end{abstract}

Kata Kunci: Pendidikan Wanita, Filsafat Pendidikan Islam

\section{A. Pendahuluan}

Pada masa jahiliyyah, wanita tidak memiliki kedudukan di masyarakat dan cenderung diremehkan. Masyarakat hanya menganggap bahwa pekerjaan wanita hanya melahirkan, mengurus rumah dan anak. Bahkan, wanita pada saat itu dianggap bagaikan pembantu, dapat diperjualbelikan dan tidak berhak mendapatkan harta berupa mahar dan warisan. ${ }^{1}$ Sehingga, jika seseorang diberikan karunia anak perempuan, maka itu merupakan aib dan sebagian mereka menguburnya hidup-hidup. ${ }^{2}$

Ketika Islam datang, Islam mengangkat derajat wanita dan memberikan hak-haknya. Islam mengharamkan membunuh anak perempuan yang baru lahir dan memberikan hak harta warisan dan mahar kepada wanita. Umar ibn Khattab menjelaskan:

1 Muhammad al-Ghazali dkk, Al-Mar'ah fi al-Islam, (Mesir: Mathbu'at Akhbar alYaumi, tt), h. 84.

${ }^{2}$ Muhammad ibn Jarir ath-Thabari, Jaami' al-Bayan fi Ta'wil al-Quran tahqiq Ahamd Muhammad Syakir, (Bairut: Muassasah ar-Risalah, 1420 H), jilid 17, h. 228. 


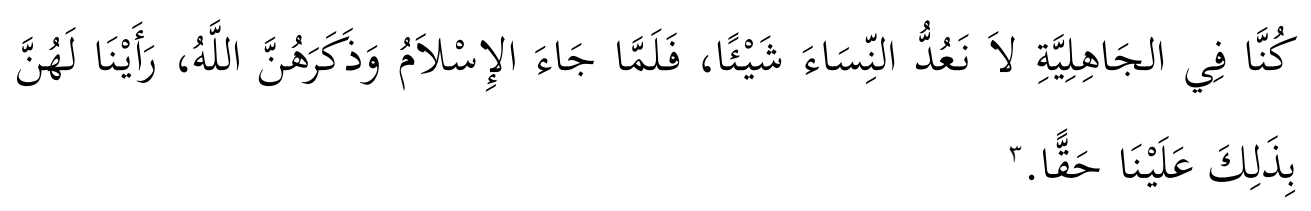

Kami pada masa jahiliyah, sama sekali tidak menganggap bagi kaum wanitu itu perkara yang penting. Ketika Islam datang dan Allah menyebut mereka, kami baru menyadari bahwa ternyata mereka juga memiliki hakhak mereka atas kami.

Termasuk hak wanita yang dijunjung tinggi oleh Islam ialah hak mendapatkan pendidikan. Rasulullullah shallallahu 'alaihi wa sallam bersabda:

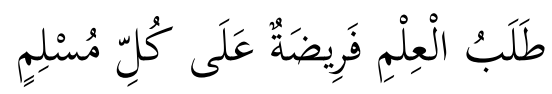

"Menuntut ilmu itu wajib atas setiap muslim". 4

Muhammad al-Ghazali menjelaskan bahwa yang dimaksud dengan "Muslim" pada hadis ini ialah mencakup pria dan wanita. Oleh sebab itu, istri-istri Nabi merupakan referensi dalam ilmu, ayat Alquran dan hadis. ${ }^{5}$

Al Rasyidin dan Ja'far mengomentari hadis ini dengan menjelaskan bahwa menuntut ilmu suatu kewajiban dalam agama Islam. Kewajiban belajar ini ditujukan kepada seluruh umat Islam tanpa pengecualian. Seluruh muslim mulai dari anak-anak sampai manula, dan pria maupun wanita, wajib menuntut ilmu. ${ }^{6}$

Maka, pada tulisan ini, akan diuraikan tentang pendidikan wanita dalam perspektif filsafat pendidikan Islam. Pembahasan pada tema ini mencakup tentang kedudukan wanita dalam Islam dan Pendidikan Wanita dalam perspektif filsafat pendidikan Islam.

\section{B. Pembahasan}

\section{a. Kedudukan Wanita Dalam Islam}

Islam datang dengan membawa ajaran mulia dan universal untuk semua manusia. Allah Ta'ala berfirman:

${ }^{3}$ Muhammad ibn Isma'il al-Bukhari, Shahih al-Bukhari, tarqim wa tartib Muhammad Fuad 'Abd al-Baqi, (Kairo: Dar Ibn Hazm, 2010), no. 5843, h. 714.

${ }^{4}$ Ibnu Majah, Sunan Ibn Majah, tahqiq Muhammad Fuad 'Abd al-Baqi, (Kairo: Dar Ihya' al-Kutub al-'Arabiah, tt), jilid 1, no. 224, h. 81.

${ }^{5}$ Muhammad al-Ghazali dkk, Al-Mar'ah fi al-Islam, h. 84. 2015), h. 9 .

${ }^{6}$ Al Rasyidin dan Ja'far, Filsafat Ilmu Dalam Tradisi Islam, (Medan: Perdana Publishing, 


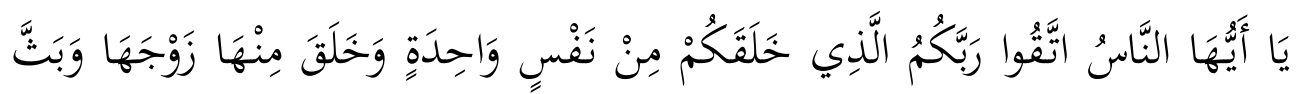

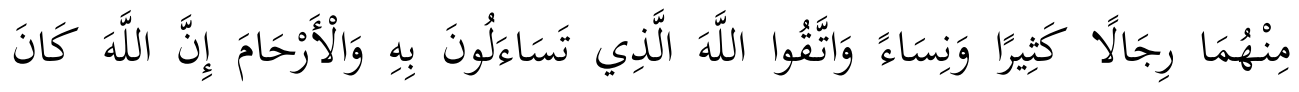

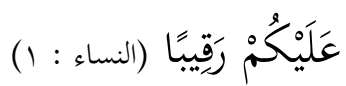

"Hai sekalian manusia, bertakwalah kepada Tuhan-mu yang telah menciptakan kamu dari diri yang satu, dan daripadanya Allah menciptakan istrinya; dan daripada keduanya Allah memperkembang biakkan laki-laki dan perempuan yang banyak." (QS. An-Nisa : 1).

Menurut Fakhuruddin ar-Razi bahwa seruan untuk bertakwa kepada Allah (menjalankan segala perintah-Nya dan menjauhi larangan-Nya) berlaku umum untuk semua manusia (termasuk wanita). ${ }^{7}$

Dan telah diyakini bahwa tidak ada satu teks pun, baru ataupun lama, yang berhubungan dengan kaum wanita dalam seluruh aspek dengan begitu singkat, fasih, mendalam dan asli seperti ketetapan ayat di atas. ${ }^{\mathbf{8}}$

Oleh sebab itu, wanita dalam Islam memiliki peran yang penting di beberapa aspek kehidupan. Di antaranya:

\section{Aspek Agama}

Islam memberikan bukti yang nyata bahwa wanita benar-benar setara dengan pria di mata Allah dalam hal hak dan kewajibannya. Dalam Alquran Allah menyatakan:

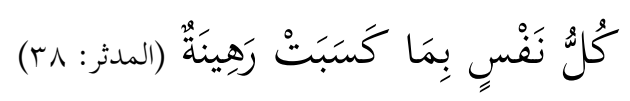

“Tiap-tiap diri bertanggung jawab atas apa yang telah diperbuatnya. ”(QS. Al-Muddatstsir : 38)

Dan dalam ayat yang lain Allah menjelaskan:

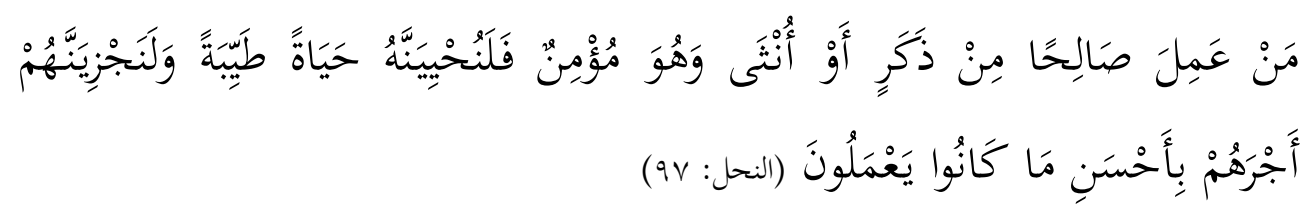

"Barangsiapa yang mengerjakan amal saleh, baik laki-laki maupun perempuan dalam keadaan beriman, maka sesungguhnya akan Kami berikan kepadanya kehidupan yang baik, dan sesungguhnya akan Kami beri h. 84 .

${ }^{7}$ Fakhruddin ar-Razi, Mafatih al-Ghaib, (Bairut: Dar Ihya’ at-Turats al-`Arabi, 1420H),

${ }^{8}$ Encyclopedia Britannica, The Encyclopedia Britannica, (Chicago,1986), h. 23. 
balasan kepada mereka dengan pahala yang lebih baik dari apa yang telah mereka kerjakan." (QS. An-Nahl : 97)

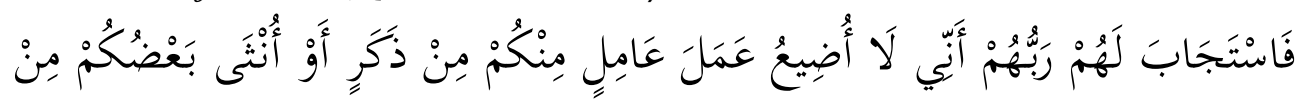

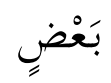

"Maka Tuhan mereka memperkenankan permohonannya (dengan berfirman): "Sesungguhnya Aku tidak menyia-nyiakan amal orang-orang yangberamal di antara kamu, baik laki-laki atau perempuan, (karena) sebagian kamu adalah turunan dari sebagian yang lain.” (QS Al-Imran: 195)

Dalam perkara batasan kewajiban dalam Islam, seperti shalat lima waktu sehari semalam, puasa, zakat, haji, maka kewajiban-kewajiban ini bagi wanita tidak berbeda dengan pria. Bahkan dalam beberapa kasus, wanita mempunyai beberapa kekhususan atas pria. Contoh, wanita diperbolehkan meninggalkan shalat dan puasa dalam masa menstruasi dan empat puluh hari saat nifas. Jika yang ditinggalkan adalah puasa wajib Ramadhan, dia boleh mengganti hari yang tertinggal tersebut kapanpun dia bisa mengqadhanya. Dan wanita tidak perlu mengganti shalat karena udzur yang disebutkan di atas. Ibunda kaum muslimin, Aisyah radhiyallahu 'anha menjelaskan:

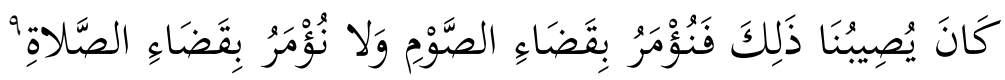

"Kami (para wanita) mengalami haidh, maka kami diperintahkan untuk mengqadha' puasa dan tidak diperintah untuk mengqqadha' shalat".

Ini menunjukkan bahwa ajaran Islam mempertimbangkan keadaan perubahan fisiologis dan psikologis yang berhubungan dengan fungsi kewanitaan yang alamiah. ${ }^{10}$

\section{Aspek Politik}

Jika kita cermati dalam Alquran maupun sejarah Islam, kita akan dapati bahwa wanita juga memiliki partisipasi dalam diskusi dan berargumen bahkan

\footnotetext{
${ }^{9}$ Muslim, Shahih Muslim, tarqim wa tartib Muhammad Fuad 'Abd al-Baqi, (Kairo: Dar Ibn Hazm, 2010), no. 335, h. 100.

${ }^{10}$ Nawal as-Sadawi, Wajah Telanjang Perempuan (Yogyakarta: Pustaka Pelajar, 2003), h. 215.
} 
dengan Nabi sallallahu alaihi wasallam. Dalam surat Al-Mujadilah ayat 1 disebutkan:

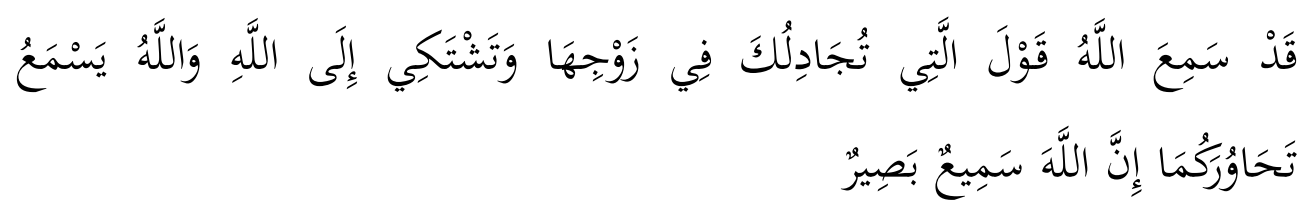

"Sesungguhnya Allah telah mendengar perkataan wanita yang mengajukan gugatan kepada kamu tentang suaminya, dan mengadukan (halnya) kepada Allah. Dan Allah mendengar soal jawab antara kamu berdua. Sesungguhnya Allah Maha Mendengar lagi Maha Melihat.”

Pada masa pemerintahan Khalifah Umar ibn Khaththab radiallahu anha, seorang wanita membantahnya dalam masjid ketika beliau menyampaikan pidato tentang mahar. Maka, ketika itu Umar mengatakan sebagai pengakuan kebenaran wanita yang membantahnya, "Wanita ini benar dan Umar salah." 11

Memang ada hadis yang menjelaskan tentang larangan wanita memimpin suatu kaum. Yaitu hadis yang terdapat dalam Shahih al-Bukhari:

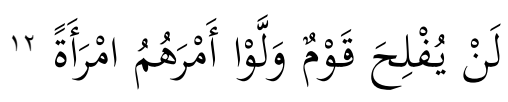

“Tidak beruntung suatu masyarakat jika mereka memilih wanita menjadi pemimpin mereka."

Keterbatasan ini tidak ada hubungannya dengan martabat atau hak wanita. Hal ini lebih pada perbedaan alamiah dari segi biologis dan psikologis.

Menurut ajaran Islam, pemimpin suatu Negara tidak sekedar simbol. Dia memimpin masyarakatnya dalam shalat, khususnya pada shalat Jumat dan Ied, Dia secara terus-menerus terikat dalam proses pengambilan keputusan menyangkut masalah keamanan dan kemaslahatan masyarakatnya. Posisi yang penuh tuntutan ini, atau yang semisalnya, seperti pimpinan angkatan bersenjata, secara umum tidak sejalan dengan kondisi fisiologis dan psikologis wanita pada umumnya. Adalah fakta klinis bahwa dalam masa menstruasi dan kehamilan, wanita mengalami perubahan fisiologis dan psikologis. Perubahan seperti itu dapat terjadi dalam keadaan darurat, hingga mempengaruhi keputusannya. Bahkan di zaman moderen, dan di negara-negara maju, sangat jarang dijumpai seorang

\footnotetext{
${ }^{11}$ Mahmud ibn 'Amr az-Zamakhsyari, Al-Kasysyaf 'an Haqaiq Ghawamid at-Tanzil, (Bairut: Dar al-Kitab al-'Arabi, 1407), jilid 1, h. 81.

12 Al-Bukhari, Shahih al-Bukhari, no. 4425, h. 533.
} 
wanita menjadi kepala negara, berperan lebih dari sekedar symbol, seorang wanita yang menjadi komandan angakatan bersenjata, atau bahkan jumlah proporsional wanita sebagai anggota parlemen, atau lembaga sejenis. Seseorang tidak mungkin menganggap hal ini sebagai ketertinggalan beberapa negara atau lembaga konsitusi terhadap hak-hak wanita untuk menduduki jabatan kepala pemerintahan atau anggota parlemen. Adalah lebih masuk akal untuk menjelaskan keadaan masa kini dalam batasan perbedaan natural dan tidak terbantahkan antara pria dan wanita, perbedaan yang tidak menyiratkan 'supermasi' pria terhadap wanita. Perbedaan ini lebih menyiratkan pada peran "saling mengisi" dari keduanya dalam kehidupan ini. ${ }^{13}$

\section{Aspek Sosial}

a. Sebagai Anak dan Orang Dewasa

Pada masa jahiliyah, anak perempuan merupakan aib. Bahkan, sebagian suku arab waktu itu tega mengubur anaknya hidup-hidup karena merasa tidak sanggung menanggung aib memiliki anak perempuan. Ketika Islam datang, Islam melarang hal tersebut, dan menganggapnya sebagai sebuah kejahatan pembunuhna.

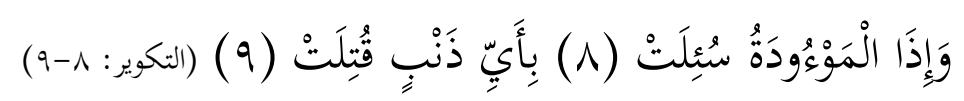

"Dan apabila bayi-bayi perempuan yang dikubur hidup-hidup ditanya, karena dosa apakah dia dibunuh." (QS At-Takwir : 8-9).

Islam juga mencela perbuatan yang dilakukan beberapa orang tua yang menolak kelahiran anak perempuan.

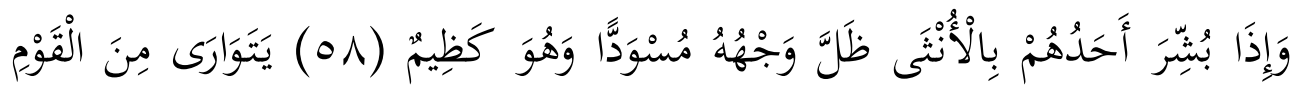

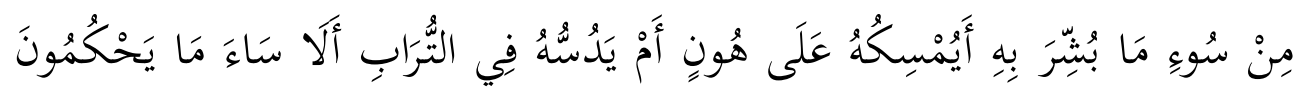

$$
\begin{aligned}
& \text { (النحل:09-01) (09) }
\end{aligned}
$$

"Dan apabila seseorang dari mereka diberi kabar dengan (kelahiran) anak perempuan, hitamlah (merah padamlah) mukanya, dan dia sangat marah. Ia menyembunyikan dirinya dari orang banyak, disebabkan buruknya berita yang disampaikan kepadanya. Apakah dia akan memeliharanya dengan menanggung kehinaan ataukah akan menguburkannya ke dalam tanah

${ }^{13}$ M. Subhi Ridho, Perempuan, Agama dan Demokrasi, (Yogyakarta: LSIP, 2007), h.75. 
(hidup-hidup) ?. Ketahuilah, alangkah buruknya apa yang mereka tetapkan itu." (QS An-Nahl : 58-59).

Islam bahkan memerintahkan berbuat baik dan adil kepada anak perempuan sebagaimana dalam hadis Nabi shallallahu 'alaihi wa sallam disebutkan:

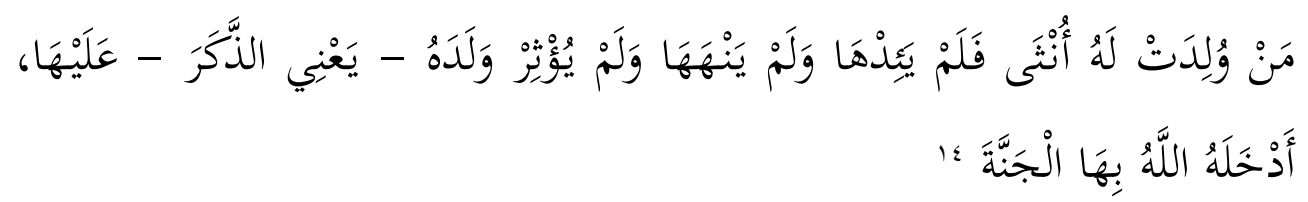

"Barangsiapa yang memiliki anak perempuan dan tidak menguburkannya hidup-hidup, tidak mempermalukannya, dan tidak melebihkan anak laki-laki atasnya, Allah akan memasukkannya ke dalam surga."

b. Sebagai Isteri

Islam dengan terang menjelaskan bahwa perkawinan adalah perpaduan antara dua setengah dari masyarakat, dan bahwa tujuannya, selain meneruskan generasi manusia, adalah untuk pemuasan kebutuhan emosional dan keseimbangan spiritual. Landasannya adalah cinta dan kasih sayang.

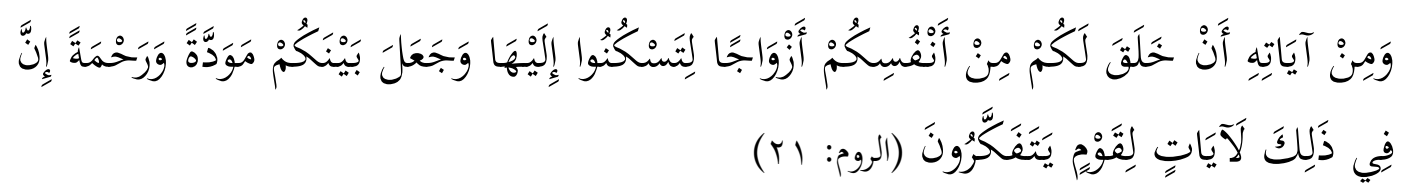

"Dan di antara tanda-tanda kekuasaan-Nya ialah Dia menciptakan untukmu istri-istri dari jenismu sendiri, supaya kamu cenderung dan merasa tenteram kepadanya, dan dijadikan-Nya di antaramu rasa kasih dan sayang. Sesungguhnya pada yang demikian itu benar-benar terdapat tandatanda bagi kaum yang berpikir." (QS. Ar-Rumm : 21)

Dalam Islam, seorang wanita tidak boleh dipaksa untuk menikah tanpa persetujuannya. Dalam Shahih al-Bukhari disebutkan bahwa Khansa binti Khidzam dipaksa nikah oleh ayahnya. Maka, Nabi shallallahu 'alaihi wa sallam menolak paksaaan nikah tersebut. ${ }^{15}$ Ibnu Abbas juga meriwayatkan:

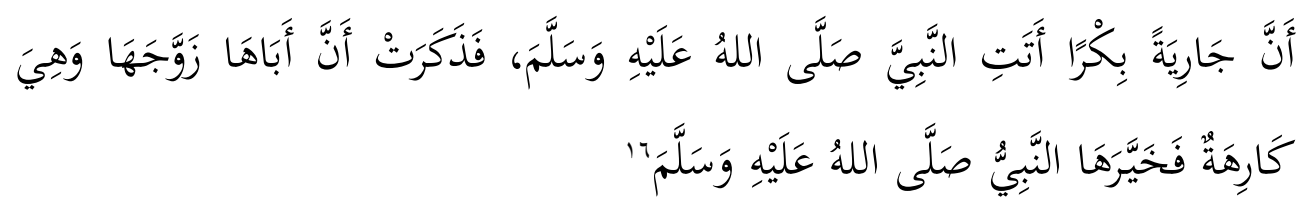

${ }^{14}$ Al-Hakim, Al-Mustadrak 'ala Shahihaini tahqiq Musthafa Abdul Qadir 'Atha, (Bairut: Dar al-Kutub al-Ilmiah, $1411 \mathrm{H}$ ), jilid 4, no. 7348, h.196.

${ }^{15}$ Al-Bukhari, Shahih al-Bukhari, no. 6969, h. 832.

${ }^{16}$ Ahmad ibn Hanbal, Musnad al-Imam Ahmad ibn Hanbal tahqiq Syuaib al-Arnauth, (tanpa tempat: Muassasah ar-Risalah, $1421 \mathrm{H})$, jilid 4, no. 2469, h. 275. 
Bahwa seorang wanita datang kepada Rasulullah shallallahu alaihi wasallam, dan dia menceritakan bahwa ayahnya telah memaksanya untuk menikah tanpa persetujuannya. Rasulullah shallallahu alaihi wasallam memberinya dua pilihan.

Selain apa yang diperoleh untuk melindunginya dalam perkara perkawinan, wanita juga secara khusus memiliki hak penuh atas maharnya, hadiah perkawinan, yang diberikan kepadanya oleh suaminya dan hal tersebut termasuk dalam akad perkawinan, dan bahwa kepemilikan tersebut tidak dapat dipindahkan kepada ayahnya atau suaminya. ${ }^{17}$

c. Sebagai Ibu

Islam memerintahkan kepada manusia agar berbuat baik kepada kedua orang tua setelah perintah untuk beribadah kepada Allah. Allah berfirman:

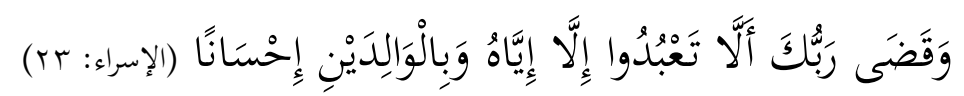

"Dan Tuhanmu telah memerintahkan supaya kamu jangan menyembah selain Dia dan hendaklah kamu berbuat baik pada ibu bapakmu dengan sebaik-baiknya." (QS. Al-Israa' : 23)

Lebih lanjut, Islam memberikan anjuran khusus berbuat baik kepada ibu. Dalam Shahih al-Bukhari disebutkan:

$$
\begin{aligned}
& \text { جَاءَ رَجُلوٌ إِلَى رَسُولِ اللَّهِ صَلَّى اللهُ عَلَيْهِ وَسَلَّمَ فَقَالَ: يَا رَسُولَ اللَّهِه مَنْ أَحَقُّ }
\end{aligned}
$$

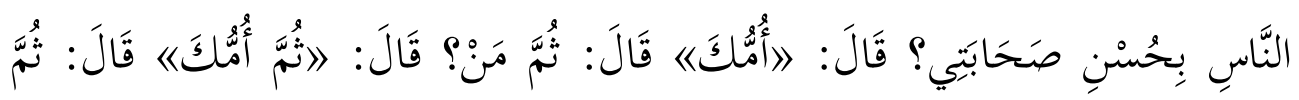

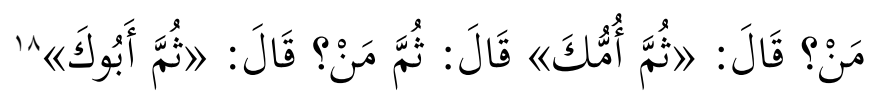

Seorang laki-laki datang kepada Nabi Muhammad sallallahu alaihi wasallam dan bertanya: "Ya Rasulullah, siapa di antara manusia yang paling berhak aku pergauli degan baik?" Rasulullah sallallahu alaihi wasallam menjawab, "Ibumu." Dia bertanya lagi, "Kemudian siapa?" Rasulullah sallallahu alaihi wasallam menjawab, "Ibumu." Dia bertanya, "Lalu siapa lagi?" Beliau menjawab, "Ibumu." Dia bertanya lagi, "Kemudian siapa?" Rasulullah shallallahu alaihi wasallam menjawab, "Kemudian ayahmu."

17 Muhammad Nawawi ibn Umar, Wanita Dalam Islam, (Jakarta: Dar al-Kutub alIslamiyyah, 2007), h. 9.

${ }^{18}$ Al-Bukhari, Shahih al-Bukhari, no. 5971, h. 725. 
Hadis ini menunjukkan betapa besar peran dan kedudukan seorang ibu yang merupakan dari kalangan wanita dalam Islam. ${ }^{19}$

\section{Aspek Ekonomi}

Islam menetapkan hak yang hilang dari wanita pada masa sebelum Islam dan sesudahnya, yaitu hak kepemilikan yang independent. Menurut hukum Islam, hak-hak wanita terhadap uang, barang, dan jenis harta lainnya diakui secara penuh. Hak ini berjalan tanpa perubahan apakah dia bertatus belum menikah atau menikah. Dia memiliki hak untuk membelanjakan, menjual, menggadaikan atau menyewakan apa saja dari hartanya. Yang penting bahwa hak tersebut berlaku untuk harta yang didapatkan sebelum menikah ataupun sesudahnya.

Mengenai hak wanita untuk bekerja, harus ditegaskan sebelumnya bahwa Islam memandang tugasnya dalam masyarakat sebagai ibu dan isteri sebagai peranan yang sangat suci dan penting. Tugas yang mulia dan vital ini, yang secara luas membentuk masa depan bangsa, tidak dapat dikatakan "tidak berbuat apaapa”. Namun demikian, tidak ada satupun ketetapan dalam Islam yang melarang wanita bekerja manakala ada kebutuhan untuk itu, khususnya pada pekerjaan yang sesuai dengan kewanitaanya dan dimana masyarakat lebih membutuhkannya. Contoh dari profesi ini adalah perawat, pengajar. Bahkan dalam posisi sebagai hakim, dimana ada kecenderungan untuk meragukan kemampuan wanita pada posisi tersebut mengingat sifat emosional alamiahnya, kita temukan sebelumnya para ulama seperti Abu Hanifa dan At- Tabary menegaskan hal itu tidak mengapa.

Selanjutnya, Islam mengembalikan hak wanita dalam hal warisan, setelah sebelumnya dia hanyalah objek yang diwariskan pada beberapa budaya. Warisannya adalah merupakan hak miliknya dan tidak ada yang dapat mengklaim warisan tersebut darinya, termasuk ayah dan suaminya. Dalam Alquran Allah menjelaskan:

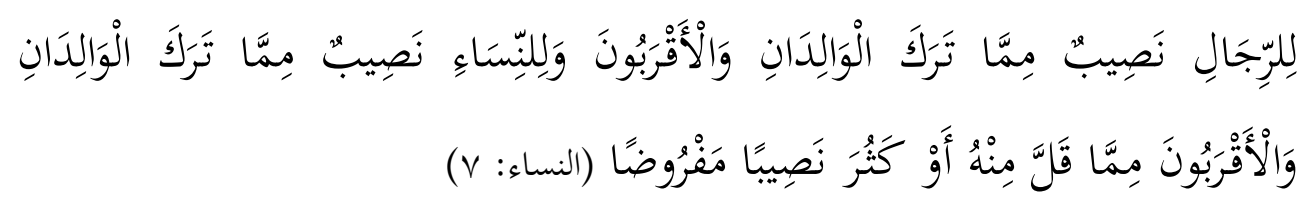

${ }^{19}$ Fatimah Mernissi, Perempuan dalam Tradisi Islam Pasca Patriarkh, (Yogyakarta: LSPPA Yayasan Prakarsa,1995), h. 89. 
"Bagi orang laki-laki ada hak bagian dari harta peninggalan ibu-bapak dan kerabatnya, dan bagi orang wanita ada hak bagian (pula) dari hartapeninggalan ibu-bapak dan kerabatnya, baik sedikit atau banyak menurut bahagian yang telah ditetapkan."(QS. An-Nisa: 7)

Dalam hal ini bagian wanita adalah setengah dari bagian pria, ini tidak berarti bahwa wanita bernilai setengah daripada pria. Secara nyata akan terlihat tidak sejalan begitu banyak bukti perlakuan yang setara terhadap wanita untuk kesimpulan semacam itu. Perbedaan dalam hak waris ini hanya sejalan dengan perbedaan dalam tanggung jawab keuangan pria dan wanita menurut hukum Islam. Di sisi lain, wanita jauh lebih terjamin dalam hal keuangan dan tidak terbebani dengan segala jenis tuntutan terhadap harta pribadinya. Harta pribadi sebelum menikah tidak berpindah kepada suaminya dan dia bahkan tetap menggunakan nama aslinya sebelum menikah. Pengkajian terhadap hukum waris dalam kesatuan kerangka hukum islam menunjukkan tidak saja Islam berlaku adil tetapi juga sangat menaruh perhatian pada wanita. ${ }^{20}$

\section{b. Pendidikan Wanita Dalam Perspektif Filsafat Pendidikan Islam}

Muhammad 'Athiyyah al-Abrasyi menjelaskan dalam bukunya, At-Tarbiyah al-Islamiyah wa Falasafatuha:

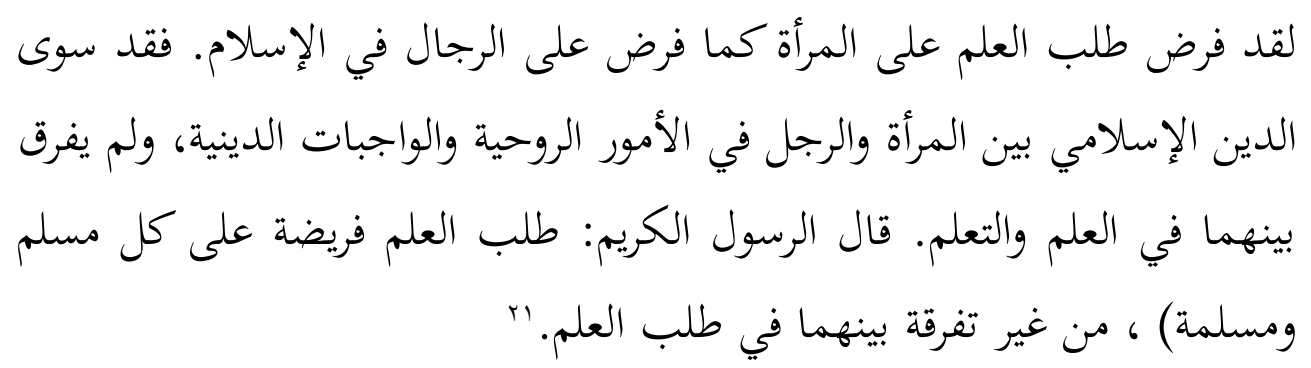

Menuntut ilmu itu diwajibkan atas wanita sebagaimana diwajibkan atas pria dalam Islam. Islam menyetarakan antara wanita dan pria dalam perkaraperkara rohani dan kewajiban agama tanpa membedakan antara keduanya dalam ilmu dan belajar. Rasulullah shallallahu alaihi wasallam bersabda: "Menuntut ilmu itu wajib atas setiap muslim dan muslimah". Tanpa membedakan antara pria dan wanita dalam menuntut ilmu.

Jika kita cermati defenisi pendidikan menurut para ahli, maka tidak ada yang membedakan antara pendidikan pria dan wanita. Semuanya menyatakan

20 Murtada Muthahhari, The Right of Women in Islam, (Jakarta: Lentera, 2001), h. 5.

21 Muhammad 'Athiyyah al-Abrasyi, At-Tarbiyah al-Islamiyah wa Falasafatuha, (Bairut: Dar al-Fikr al-'Arabi, tt), h. 123. 
bahwa wanita mempunyai hak yang sama dalam pendidikan. Sayid Sabiq dalam kitabnya "Islamuna", bahwa pendidikan adalah usaha untuk mempersiapkan anak baik dari segi jasmani, segi akal, dan segi rohaninya sehingga dia menjadi anggota masyarakat yang bermanfaat, baik untuk dirinya maupun bagi umatnya. ${ }^{22}$ Anwar Jundi dalam kitabnya "at-Tarbiyyah wa Bina al-Ajyal fi Dhaui al-Islam", menyatakan bahwa yang dimaksud dengan pendidikan adalah menumbuhkan manusia dengan pertumbuhan yang terus menerus sejak ia lahir sampai meninggal dunia. ${ }^{23}$ Sedangkan Athiyah al-Abrasyi, mendefiniskan pendidikan sebagai upaya untuk mempersiapkan individu agar ia dapat hidup dengan kehidupan yang sempurna. ${ }^{24}$ Dari ketiga definisi di atas, nampak jelas tidak mengandung perbedaan yang prinsipil, malah saling memberikan penguatan bahwa pendidikan itu sebagai usaha mempersiapkan dan menumbuhkan individu manusia dari sejak ia lahir sampai akhir hayat untuk memiliki kekuatan jasmani, akal, dan rohani bagi manusia, tidak hanya pada diri lelaki, tetapi juga perempuan berdasarkan nilai-nilai keislaman.

Islam sangat mendorong pendidikan perempuan baik dalam bidang agama maupun sosial. Tidak ada prioritas bagi laki-laki di atas perempuan dalam kaitannya dengan hak atas pendidikan. Keduanya sama-sama terdorong untuk mendapatkan pendidikan, sebagaimana dikatakan, 'dari buaian sampai liang kubur'. Sesungguhnya semua ayat Alquran yang berhubungan dengan pendidikan dan yang mengadvokasi perolehan pengetahuan diarahkan baik kepada pria maupun wanita. Sesuai dengan konsep tauhid ketika Islam mengangkat wanita secara fisik dengan menghapus pembunuhan bayi perempuan, itu tidak dapat mengabaikan kebutuhan akan peningkatan mental dan spiritual mereka. ${ }^{25}$

Alquran dan hadis tidak pernah melarang wanita untuk belajar dan memiliki pendidikan. Nabi shallallahu 'alaihi wa sallam juga sudah menekankan bahwa belajar itu wajib atas setiap muslim tanpa membedakan pria maupun wanita dalam sabdanya:

22 Sayid Sabiq, Islamuna, (Bairut: Dar al-Kitab al-'Arabi, tt), tanpa halaman.

23 Anwar Jundi, At-Tarbiyah wa Bina al-Ajyal fi Dhaui al-Islam, (Bairut: Dar al-Kitab, 1975), h. 160.

24 Al-Abrasyi, At-Tarbiyah al-Islamiyah wa Falasafatuha, h. 48.

${ }^{25}$ Mohammad Saiful Islam, Importance of Girls' Education as Right: A Legal Study From Islamic Approach (Beijing, 2016) h. 20. 


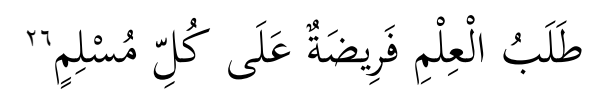

“Menuntut ilmu itu wajib atas setiap muslim”.

Dengan penekanan ini, Nabi shallallahu 'alaihi wa sallam membuka semua jalan pengetahuan untuk pria dan wanita. Jadi, setiap wanita berada di bawah kewajiban moral dan agama untuk mencari pengetahuan, mengembangkan kecerdasannya, memperluas pandangannya, menumbuhkan bakatnya dan kemudian memanfaatkan potensinya untuk manfaat jiwanya dan masyarakatnya.

Bahkan, jika kita kaji, ternyata Nabi shallallahu 'alaihi wa sallam memberikan waktu secara khusus untuk mendidik para wanita. Dalam Shahih alBukhari disebutkan:

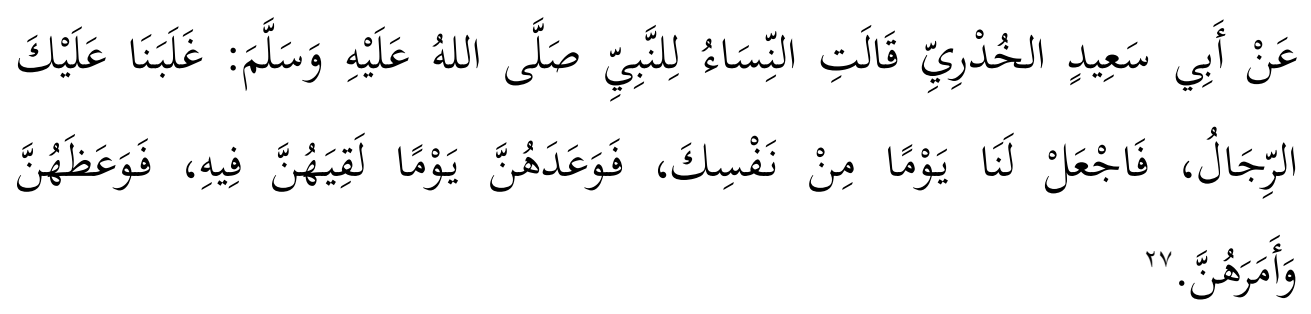

Dari Abu Said al-Khudri, dia berkata, beberapa wanita mengatakan kepada Nabi, 'Kaum pria mengalahkan kami, maka jadikanlah satu hari untuk kami belajar darimu. Maka Nabi menjanjikan bagi mereka satu hari untuk bertemu dan menasehati mereka.

Dan Aisyah radhiyallahu 'anhu pernah memuji wanita Anshar karena semangat mereka dalam belajar sebagai bentuk motivasi bagi seluruh wanita muslimah untuk terus dan bersemangat dalam menuntut ilmu. Dalam Shahih alBukhari disebutkan bahwa berkata:

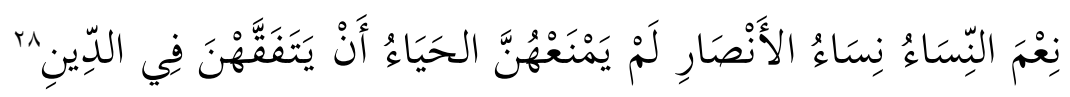

Sebaik-baik wanita ialah wanita Anshar, rasa malu tidak menghalangi mereka untuk memahami dan mempelajari agama ini.

Syaikh Shalih as-Sadlan menjelaskan tentang bagaimana wanita-wanita muslimah pada masa Nabi begitu semangat dalam belajar dan di antara mereka

\footnotetext{
${ }^{26}$ Ibnu Majah, Sunan Ibn Majah, jilid 1, no. 224, h. 81.

27 Al-Bukhari, Shahih al-Bukhari, no. 101, h. 23.

28 Al-Bukhari, Shahih al-Bukhari, h. 38.
} 
dikenal dengan keilmuan dan keahliannya. Diringkas dalam Majalah alAshalah ${ }^{29}$ beliau menjelaskan:

Dalam konteks kesetaraan derajat wanita dan lelaki dalam mendapatkan ilmu ini, sungguh tidak ada yang lebih membuktikannya daripada keberadaan wanita muslimah dalam naungan Islam. Mereka telah mencapai derajat yang tinggi dalam keilmuan.

Lihatlah para sahabiyyah (sahabat wanita), mereka semangat mengerjakan shalat jamaah bersama Nabi shallallahu 'alaihi wa sallam di masjid, sepaya bisa memperoleh pengejaran dari Nabi shallallahu 'alaihi wa sallam. Padahal semua bersepakat tanpa ada perbedaan pendapat, bahwa seorang wanita melaksanakan shalat di rumah, itu lebih afdhal daripada shalat di masjid. Kemudian, dikarenakan jumlah mereka banyak, akhirnya Rasulullah Shallallahu 'alaihi wa sallam mengkhususkan sebuah pintu masjid bagi mereka hingga sampai sekarang ini di masjid Nabawi, yang diberi nama "Babun Nisaa", artinya pintu khusus untuk para wanita.

Al-Baladzuri menyebutkan dalam kitab Fûhul Buldân: "Jumlah wanita muslimah terdahulu yang mempelajari baca tulis adalah separo jumlah laki-laki yang mampu baca tulis.” Al-Baladzuri juga menceritakan bahwasanya Ummu Kultsûm binti 'Uqbah cakap dalam menulis.

Diriwayatkan bahwa asy-Syifâ' al-Adawiyah dari Bani (Suku) 'Adi, keluarga besar 'Umar bin Khaththab diminta Nabi untuk mengajarkan kepada istri beliau Shallallahu 'alaihi wa sallam, yaitu Ummul-Mukminiin Hafshah binti 'Umar bin Khaththâb cara menulis indah.

Ummul-Mukminiin 'Aisyah binti Abi Bakar dan Ummul-Mukminîn Ummu Salamah juga memiliki kemampuan membaca, walaupun belum sampai pada derajat mahir dalam menulis. Al-Wâqidi menyebutkan bahwa Karîmah binti alMiqdâd bisa membaca dan menulis.

Aisyah binti Sa'ad berkata: “Ayahku telah mengajarkan kepadaku tulismenulis".

Begitu pula dalam hal pengajaran, para wanita sahabiyyah juga mampu berkompetisi dengan kaum laki-laki. Misalanya, seperti halnya 'Aisyah

\footnotetext{
${ }^{29}$ Shalih as-Sadlan, Majalah al-Ashalah, Edisi 29, Tahun V, 15 Sya'ban $1421 \mathrm{H}$.
} 
radhiyallahu 'anha telah meriwayatkan kurang lebih dua ribu hadits, begitu pula saudarinya yang bernama Asma' juga telah meriwayatkan sekitar 50 hadits. Dan masih banyak lagi di antara muslimah sahabiyyah selain keduanya yang banyak meriwayatkan banyak hadits dari Rasulullah shallallahu 'alaihi wa sallam.

Ummu Darda' yang dikaruniai ilmu pernah berkata: "Sungguh aku telah merasakan dan menjalankan berbagai macam ibadah, namun yang paling bisa merasuk dan menyembuhkan jiwaku ialah tatkala duduk dan dzikir di hadapan para ulama".

Imam Nawawi sendiri mengakui kefaqihan Ummu Darda' ini dengan pujiannya: "Semua telah bersepakat tentang kefaqihan dan kehebatan Ummu Darda` dalam hal pemikiran dan pemahaman. Beliau radhiyallahu 'anhuma hidup pada masa Mu'awiyyah".

Demikianlah, Islam tidak melarang para wanita untuk belajar agama. Tidak mengapa bagi para wanita untuk mencari jalan kemajuan bagi dirinya. Bahkan para ahlu ilmi dan ahli fiqh zaman terdahulu maupun sekarang sepakat, bahwa menuntut ilmu syar'i yang menjadi kebutuhan pokok adalah fardhu 'ain atas mereka. Tidak ada perbedaan antara laki-laki dengan perempuan dalam hal ini. Laki-laki dan perempuan kedudukan yang sama dalam kewajiban bersyariat, dan begitu pula dalam mendapatkan balasan di akhirat, kecuali dalam beberapa aturan syariat tertentu, Allah Subhanahu wa Ta'ala membebaskan kaum wanita dari tugas tersebut. Baik, karena aturan-aturan itu mengandung unsur yang memberatkan wanita dalam menjalankannya, atau karena memang tidak sesuai dengan tabiat wanita, atau lantaran bertentangan dengan tugas utama penciptaannya, atau mengakibatkan kerusakan sosial seperti seperti ikhtilâth (percampuran antara laki-laki dan perempuan) dan lain-lain. Adapun aturan-aturan agama lainnya, wanita memiliki kesamaan dengan kaum lelaki dalam mengemban kewajiban-kewajiban dan aturan-aturan syariat.

Al-Abrasyi juga menjelaskan hal yang serupa tentang bagaimana wanitawanita muslimah pada masa Nabi Shallallahu 'alaihi wa sallam dan kekhilafahan Islam bersemangat dalam belajar dan di antara mereka terkenal sebagai wanitawanita cerdas. ${ }^{30}$

30 Al-Abrasyi, At-Tarbiyah al-Islamiyah wa Falasafatuha, h. 123-127. 
Wanita diizinkan untuk mempelajari semua cabang ilmu pengetahuan. Dia bebas memilih bidang pengetahuan yang menarik baginya. Meskipun demikian, penting untuk ditekankan bahwa, karena Islam mengakui bahwa perempuan pada dasarnya adalah istri dan ibu, mereka juga harus menempatkan penekanan khusus pada pencarian pengetahuan di cabang-cabang yang dapat membantu mereka dalam bidang-bidang tertentu itu. ${ }^{31}$

\section{Kesimpulan}

Wanita dalam Islam memiliki hak yang sama dalam pendidikan. Nabi secara umum menjelaskan bahwa belajar itu wajib hukumnya atas setiap muslim termasuk wanita.

Islam tidak melarang para wanita untuk belajar agama. Tidak mengapa bagi para wanita untuk mencari jalan kemajuan bagi dirinya. Bahkan para ahlu ilmi dan ahli fiqh zaman terdahulu maupun sekarang sepakat, bahwa menuntut ilmu syar'i yang menjadi kebutuhan pokok adalah fardhu 'ain atas mereka. Tidak ada perbedaan antara laki-laki dengan perempuan dalam hal ini. Laki-laki dan perempuan kedudukan yang sama dalam kewajiban bersyariat, dan begitu pula dalam mendapatkan balasan di akhirat, kecuali dalam beberapa aturan syariat tertentu, Allah Subhanahu wa Ta'ala membebaskan kaum wanita dari tugas tersebut.

Dalam sejarah Islam, sejak masa Nabi dan kekhilafahan Islam, wanita menempuh pendidikan dan di antara mereka dikenal sebagai wanita-wanita berilmu serta dijadikan sebagai rujukan. Seperti, Aisyah, Khansa', Lubna dan lain-lain.

Wanita diizinkan untuk mempelajari semua cabang ilmu pengetahuan. Dia bebas memilih bidang pengetahuan yang menarik baginya. Meskipun demikian, penting untuk ditekankan bahwa, karena Islam mengakui bahwa perempuan pada dasarnya adalah istri dan ibu, mereka juga harus menempatkan penekanan khusus pada pencarian pengetahuan di cabang-cabang yang dapat membantu mereka dalam bidang-bidang tertentu itu.

${ }^{31}$ Haifaa Jawad, The Right of Women in Islam An Authetic Approach, (Macmillan Press ltd: 1998), h. 21. 


\section{Pustaka Acuan}

Ahmad ibn Hanbal. Musnad al-Imam Ahmad ibn Hanbal tahqiq Syuaib alArnauth. tanpa tempat: Muassasah ar-Risalah, $1421 \mathrm{H}$.

Al Rasyidin dan Ja'far. Filsafat Ilmu Dalam Tradisi Islam. Medan: Perdana Publishing, 2015.

Al-Abrasyi, Muhammad 'Athiyyah. At-Tarbiyah al-Islamiyah wa Falasafatuha. Bairut: Dar al-Fikr al-'Arabi, tt.

Al-Bukhari, Muhammad ibn Isma'il. Shahih al-Bukhari, tarqim wa tartib Muhammad Fuad 'Abd al-Baqi. Kairo: Dar Ibn Hazm, 2010.

Al-Ghazali, Muhammad, dkk. Al-Mar'ah fi al-Islam. Mesir: Mathbu'at Akhbar alYaumi, tt.

Al-Hakim. Al-Mustadrak 'ala Shahihaini tahqiq Musthafa Abdul Qadir 'Atha. Bairut: Dar al-Kutub al-Ilmiah, $1411 \mathrm{H}$.

Ar-Razi, Fakhruddin. Mafatih al-Ghaib. Bairut: Dar Ihya' at-Turats al-'Arabi, $1420 \mathrm{H}$.

As-Sadawi Nawal. Wajah Telanjang Perempuan. Yogyakarta: Pustaka Pelajar, 2003.

As-Sadlan, Shalih. Majalah al-Ashâlah, Edisi 29, Tahun V, 15 Sya'ban $1421 \mathrm{H}$.

Ath-Thabari, Muhammad ibn Jarir. Jaami' al-Bayan fi Ta'wil al-Quran tahqiq Ahamd Muhammad Syakir. Bairut: Muassasah ar-Risalah, $1420 \mathrm{H}$.

Az-Zamakhsyari, Mahmud ibn 'Amr. Al-Kasysyaf 'an Haqaiq Ghawamid atTanzil,. Bairut: Dar al-Kitab al-'Arabi, 1407 H.

Encyclopedia Britannica. The Encyclopedia Britannica. Chicago, 1986.

Ibnu Majah. Sunan Ibn Majah, tahqiq Muhammad Fuad 'Abd al-Baqi. Kairo: Dar Ihya' al-Kutub al-' Arabiah, tt.

Jawad, Haifaa. The Right of Women in Islam An Authetic Approach. Macmillan Press ltd: 1998.

Jundi, Anwar. At-Tarbiyah wa Bina al-Ajyal fi Dhaui al-Islam. Bairut: Dar alKitab, 1975.

Mernissi, Fatimah. Perempuan dalam Tradisi Islam Pasca Patriarkh. Yogyakarta: LSPPA Yayasan Prakarsa,1995. 
Muslim. Shahih Muslim, tarqim wa tartib Muhammad Fuad 'Abd al-Baqi. Kairo: Dar Ibn Hazm, 2010.

Muthahhari, Murtada. The Right of Women in Islam. Jakarta: Lentera, 2001.

Nawawi, Muhammad. Wanita Dalam Islam. Jakarta: Dar al-Kutub al-Islamiyyah, 2007.

Ridho, M. Subhi. Perempuan, Agama dan Demokrasi. Yogyakarta: LSIP, 2007.

Sabiq, Sayid. Islamuna. Bairut: Dar al-Kitab al-'Arabi, tt), tanpa halaman.

Saiful Islam, Mohamma., Importance of Girls' Education as Right: A Legal Study From Islamic Approach. Beijing, 2016. 